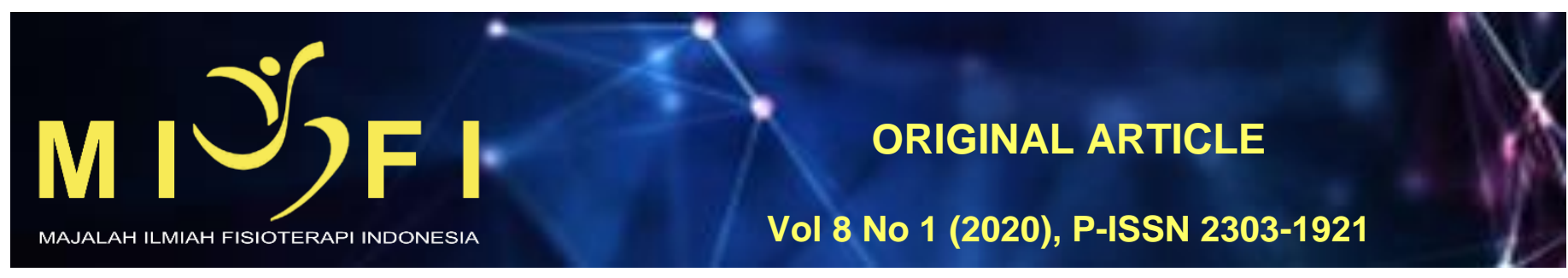

\title{
HUBUNGAN PEMBERIAN PROGRAM TAMAN KANAK-KANAK A TERHADAP PERKEMBANGAN FUNGSI MOTORIK ANAK USIA 5-6 TAHUN DI YAYASAN MUTIARA BUNDA PEMOGAN DENPASAR
}

\author{
Nacha Najabilubaba ${ }^{1}$, Ni Wayan Tianing ${ }^{2}$, M. Widnyana ${ }^{3}$, Anak Ayu Nyoman Trisna Narta Dewi ${ }^{4}$ \\ ${ }^{1}$ Program Studi Sarjana Fisioterapi dan Profesi Fisioterapi, Fakultas Kedokteran Universitas Udayana \\ ${ }^{2}$ Departemen Biokimia, Fakultas Kedokteran Universitas Udayana \\ 3,4Departemen Fisioterapi, Fakultas Kedokteran Universitas Udayana \\ nachanajabilubaba@gmail.com
}

\begin{abstract}
ABSTRAK
Perkembangan adalah hasil dari proses pematangan yang berupa bertambahnya kemampuan dan keterampilan dalam fungsi tubuh. Perkembangan pada saat usia anak ini menjadi penting karena ada yang berpendapat bahwa apa yang terjadi pada orang dewasa ditentukan dari perkembangan pada saat masih usia anak-anak. Salah satu upaya pemerintah untuk mendukung pertumbuhan dan perkembangan anak adalah Pendidikan Anak Usia Dini (PAUD), yang salah satunya yaitu TK-A. Namun, masih banyak anak usia 5-6 tahun yang belum mengikuti program tersebut sehingga menyebabkan perkembangan motoriknya lebih terlambat dibandingkan dengan anak yang mengikuti program TK-A. Penelitian ini bertujuan untuk mengetahui hubungan pemberian program TK-A terhadap perkembangan motorik pada anak usia 5-6 tahun di Yayasan Mutiara Bunda Pemogan Denpasar. Jenis penelitian ini adalah penelitian observasional analitik menggunakan rancangan cross sectional yang dilaksanakan pada bulan Maret 2019. Pengambilan sampel dilakukan menggunakan teknik total sampling dengan sampel berjumlah 42 orang.. Variabel dependen yang diukur adalah perkembangan motorik dengan pemeriksaan menggunakan lembar DDST. Variabel independen dalam penelitian ini adalah program TK-A. Uji hipotesis yang digunakan adalah Chi Square Test untuk menganalisis signifikansi hubungan antara pemberian program TK-A terhadap perkembangan motorik anak. Pada perhitungan analisis data, diperoleh nilai $p$ sebesar 0,571 sehingga $p>0,05$. Kesimpulan dari penelitian dan uji statistik tersebut adalah tidak terdapat hubungan yang signifikan antara pemberian program TK-A terhadap perkembangan motorik anak usia 5-6 tahun di Yayasan Mutiara Bunda Pemogan Denpasar.
\end{abstract}

Kata kunci: anak usia prasekolah, motorik anak, Taman Kanak-kanak A.

\section{CORRELATION OF KINDERGARTEN PROGRAM TO THE MOTORIKC DEVELOPMENT OF 5-6-YEAR-OLD CHILDREN'S MOTOR FUNCTION AT MUTIARA BUNDA FOUNDATION PEMOGAN SOUTH DENPASAR}

\begin{abstract}
Development is the result of a maturation process that consists of increasing abilities and skills in body functions. Development at the age of the child becomes important because there are those who prove that what happens to adults is determined by the development at the age of the children. One of the government assistance to support the growth and development of children in Early Childhood Education which is abbreviated as preschool, one of that is Kindergarten. However, there are still many children aged 5-6 years who have not yet participated in this program, causing more motoric development compared to children who take the Kindergarten program. This study aims to determine the relationship of the kindergarten program to motor development in children aged 5-6 years at the Mutiara Bunda Foundation Pemogan Denpasar. This type of research was an observational analytic study using a crosssectional design carried out in March 2019. Sampling was done using total sampling technique with a sample of 42 people. The dependent variable measured is motor development by examining using DDST. The independent variable in this study is the Kindergarten program. The hypothesis test used is the Chi-Square Test to analyze the significance of the relationship between the provision of Kindergarten programs on children's motor development. In the calculation of data analysis, the obtained $p$-value of 0.571 so that $p>0.05$. Based on the results of the research and statistical tests, it was concluded that there was no significant relationship between the provision of Kindergarten programs on motoric development of children aged 5-6 years at the Mutiara Bunda Foundation Pemogan Denpasar.

Keyword: preschool children, motoric, kindergarten program.
\end{abstract}




\section{PENDAHULUAN}

Perkembangan akan dilalui semua manusia. Perkembangan pada usia anak-anak akan menentukan apa yang terjadi saat dewasa ${ }^{1}$. Pola perkembangan merupakan hasil dari interaksi faktor genetik dan lingkungan ${ }^{2}$. Stimulus yang didapatkan dari lingkungan keluarga sangat berpengaruh namun berdasarkan penelitian sebelumnya masih banyak orang tua yang membutuhkan informasi terkait stimulasi yang berarti bahwa orang tua belum memahami tentang stimulasi yang harus diberikan kepada anak ${ }^{3}$. Pemerintah memiliki program PAUD salah satunya yaitu Taman Kanakkanak Kelompok A (TK-A) yang mana bertujuan untuk mendukung perkembangan anak salah satunya yaitu perkembangan motorik(kemendikbud), walaupun sudah terdapat program yang dibuat oleh pemerintah berdasarkan statisti kemendikbud masih banyak anak yang tidak mengikuti program tersebut. Peneliti melakukan observasi awal ke Yayasan Mutiara Bunda dan didapatkan banyak anak yang tidak mengikuti program TK-A dan beberapa anak yang kurang bisa melakukan tulis menulis, menggunting dan hal lain yang berhubungan dengan motorik pada anak usia 5 tahun yang tidak mengikuti TK-A.

Usia prasekolah merupakan golden period dimana menjadi masa terpenting untuk memperhatikan perkembangan anak. Pada 2 tahun terakhir masa prasekolah terjadi pertumbuhan otot-otot besar yang cukup cepat yang memungkinkan anak bisa melakukan gerakan dengan lebih leluasa dan bisa melakukan bermacam-macam gerak dasar. Pada usia ini terjadi peningkatkan kekuatan hingga mencapai $\pm 65 \%{ }^{4}$. Perkembangan motorik anak pada usia tersebut perlu diarahkan dan didukung salah satunya dengan mengikutkan anak dalam Pendidikan Anak Usia Dini (PAUD) salah satunya yaitu TK-A.

PAUD merupakan pembinaan yang berupa rangsangan pendidikan yang ditujukan kepada anak usia 0-6 tahun dalam mendukung pertumbuhan dan perkembangan anak ${ }^{5}$. Kegiatan dalam PAUD itu sendiri yaitu bermain yang bersifat edukatif sehingga membantu kesiapan anak untuk memasuki jenjang sekolah dasar baik secara psikososial, kognitif, dan motorik ${ }^{6,7,8}$. Dalam PAUD anak dilatih dan diajarkan berdasarkan Standar Nasional Kurikulum 2013 yang mana salah satunya adalah kemampuan fisik motorik.

Perkembangan motorik adalah proses aktif dimana anak harus secara aktif untuk meningkatkan keterampilannya agar perkembangan tersebut tercapai sesuai dengan usianya ${ }^{9}$.Prinsip perkembangan motorik ada 5 yaitu maturasi saraf dan otot, belajar saat siap secara matang, mengikuti pola yang dapat diprediksi, dapat ditentukan, dan berbeda tiap individu. Perkembangan motori pada anak juga ditentukan olehbeberapa faktor yaitu: (1) Motivasi belajar anak, (2) Gizi anak, (3) Lingkungan pengasuh, (4) Stimulasi, (5) Pengetahuan ibu, (6) Kesehatan anak, (7) Perumahan, (8) Sosial ekonomi, (9) Jumlah saudara, (10) Kelompok Sebaya, (11) Keluarga. Perkembangan motorik dibagi menjadi dua yaitu motorik kasar dan motori halus ${ }^{10}$. Motorik kasar yaitu keterampilan gerak tubuh yang menggunakan otot-otot besar sebagai otot utama untuk menggerakkannya ${ }^{11}$. Motorik Halus yaitu aspek yang berhubungan dengan kemampuan anak dalam melakukan gerakan yang melibatkan bagian tubuh tertentu serta dikerjakan oleh otot-otot kecil, tetapi memerlukan koordinasi yang cermat seperti mengamati sesuatu, menjumput, menulis, dan lainnya ${ }^{12}$.

Berdasarkan pendahuluan tersebut penulis ingin meneliti hubungan antara pemberian program TK-A terhadap perkembangan motorik anak pada usia 5-6 Tahun di Yayasan Mutiara Bunda Pemogan Denpasar Selatan.

\section{METODE}

Desain yang digunakan dalam penelitian ini adalah observasional analitik dengan rancangan cross sectional. Pelaksanaan penelitian dilakukan pada bulan Maret - April 2019 di Yayasan Mutiara Bunda Pemogan Denpasar Selatan. Jumlah sampel yang mengikuti penelitian ini sebanyak 42 anak. Pengambilan sampel dalam penelitian ini menggunakan metode total sampling dan memenuhi kriteria inklusi dan eksklusi. Inklusi dari penelitian ini yaitu anak dengan rentang usia 5-6 tahun, berada pada kelas TK-B pada tahun ajaran 2018/2019, dan orang tua/pengasuh sampel bersedia mengisi inform consent. Kriteria eksklusi dari penelitian ini adalah penggunaan obat hormon pertumbuhan dan perkembangan, sampel mengikuti latihan/olahraga diluar program sekolah, sampel pernah mengikuti program Kelompok Bermain, dan sampel menolak dilakukan pemeriksaan.

Penelitian ini menggunakan 3 variabel, yaitu variabel bebas, variabel terikat, dan variabel kontrol. Variabel bebas dalam penelitian ini adalah keikutsertaan anak dalam TK-A, variabel terikat dalam penelitian ini adalah perkembangan motorik kasar dan halus pada anak usia 5-6 tahun, sedangkan variabel kontrolnya yaitu usia dan presentase kehadiran dalam pembelajaran tahun ajaran 2018/2019 minimal 80\%.Pengukuran perkembangan motorik kasar dan halus dalam penelitian ini menggunakan lembar DDST. Interpretasi yang digunakan dibagi menjadi tiga kategori, yaitu Normal, Suspek, dan Abnormal.Data yang telah dikumpulkan kemudian dilakukan uji statistik chi-square untuk mengetahui signifikansi hubungan antara pemberian TK-A dengan perkembangan motorik anak.

\section{HASIL}

Sampel dalam penelitian ini memiliki usia dengan rentang 5-6 tahun berjumlah 42 sampel. Berikut adalah hasil gambaran distribusi frekuensi yang diamati antara lain keikutsertaan, usia, presentase kehadiran, serta distribusi frekuensi sampel berdasarkan kategori penilaian DDST.

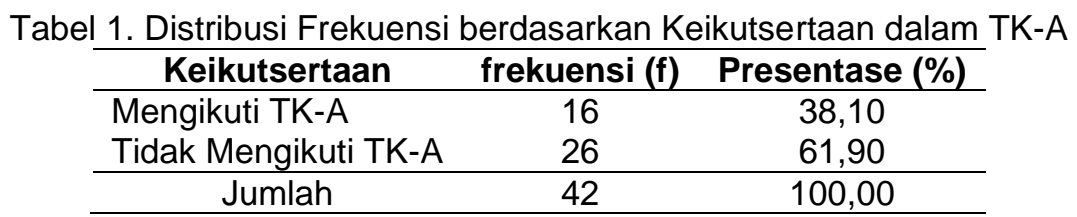

Tabel 1. Menunjukkan bahwa sampel yang mengikuti TK-A memiliki frekuensi sebanyak 16 anak, dan sampel yang tidak mengikuti TK-A sebanyak 26 anak. 
Tabel 2. Distribusi Frekuensi berdasarkan Usia

\begin{tabular}{ccc}
\hline Usia & frekuensi (f) & Presentase (\%) \\
\hline 5 tahun & 31 & 73,80 \\
6 tahun & 11 & 26,20 \\
\hline Jumlah & 42 & 100,00 \\
\hline
\end{tabular}

Tabel 2.menunjukkan bahwa sampel dengan usia 5 tahun sebanyak 31 anak dan sampel denga usia 6 tahun sebanyak 11 anak.

Tabel 3. Distribusi Frekuensi berdasarkan Presentase Kehadiran

\begin{tabular}{ccc}
\hline Presentase Kehadiran & frekuensi (f) & Presentase (\%) \\
\hline $80 \%-90 \%$ & 5 & 11,90 \\
$91 \%-100 \%$ & 37 & 88,10 \\
\hline Jumlah & 42 & 100,00 \\
\hline
\end{tabular}

Tabel 3. Menunjukkan bahwa sampel dengan presentase kehadiran $80 \%-90 \%$ sebanyak 5 anak, dan sampel dengan presentase kehadiran $91 \%-100 \%$ sebanyak 37 anak.

Tabel 4.Data Karakteristik Sampel

\begin{tabular}{cc}
\hline Karakteristik & Nilai Rerata \pm Simpang Baku \\
\hline Usia (tahun) & $5,75 \pm 0,224$ \\
Kehadiran (\%) & $87,47 \pm 3,002$
\end{tabular}

Tabel 4. Menunjukkan bahwa nilai rerata usia sampel dalam penelitian ini adalah 5,75 dengan simpang baku $\pm 0,224$, dan nilai rerata kehadiran sampel dalam penelitian ini adalah 87,47 dengan simpang baku $\pm 3,002$.

Tabel 5.Distribusi Frekuensi Sampel Berdasarkan Kategori Penilaian DDST

\begin{tabular}{ccc}
\hline Kategori & frekuensi (f) & Presentase (\%) \\
\hline Normal & 19 & 45,2 \\
Suspek & 14 & 33,3 \\
Abnormal & 9 & 21,4 \\
\hline Jumlah & 42 & 100 \\
\hline
\end{tabular}

Tabel 5. Menunjukkan bahwa sampel dengan perkembangan motorik kategori normal sebanyak 19 anak, sampel dengan kategori perkembangan motorik suspek sebanyak 14 anak dan sampel dengan perkembangan motorik abnormal sebanyak 9 anak.

Data kemudian dianalisis dengan menggunakan uji statistik chi-squareuntuk mengetahui hubungan antara dua variabel yaitu program TK-A dengan perkembangan motorik. Berikut adalah tabel uji statistik

\begin{tabular}{|c|c|c|c|c|c|}
\hline \multirow[b]{2}{*}{ Keikutsertaan } & \multicolumn{3}{|c|}{ Perkembangan motorik } & \multirow[b]{2}{*}{ Jumlah } & \multirow[b]{2}{*}{$\mathbf{P}$} \\
\hline & Normal & Suspek & Abnormal & & \\
\hline Mengikuti TK-A & 9 & 4 & 3 & 16 & \\
\hline Tidak Mengikuti TK_A & 10 & 10 & 6 & 26 & 0,517 \\
\hline Jumlah & 19 & 14 & 9 & 42 & \\
\hline
\end{tabular}

Tabel 6. menunjukkan nilai $p$ dari hasil chi-square adalah 0,517 yang berati $p>0,05$, sehing ga dapat dinyatakan bahwa pemberian program TK-A tidak berhubungan secara signifikan dengan perkembangan motorik anak usia 5-6 tahun.

\section{DISKUSI}

\section{Karakteristik Sampel Penelitian}

Penelitian telah dilakukan terhadap 42 sampel dengan rentang usia 5-6 tahun. Kategori usia 5 tahun merupakan yang terbanyak, yaitu 31 anak, dan kategori usia 6 tahun terdapat 11 anak. Hasil penelitian ini menunjukkan terdapat dua kelompok sampel. Kelompok pertama yaitu anak yang mengikuti program TK-A sebanyak 16 anak, dan kelompok kedua yaitu anak yang tidak mengikuti program TK-A sebanyak 26 anak. Hasil penelitian ini menunjukkan bahwa anak usia 5-6 tahun yang tidak mengikuti program TK-A lebih banyak dibandingkan yang mengikuti TK-A, ini sejalan dengan statistika yang dilakukan Kemendikbud dimana terdapat perbedaan dari jumlah siswa yang mengikuti program TK-A dengan program di jenjang selanjutnya ${ }^{5}$.

Hasil penelitian ini menunjukkan persentase kehadiran sampel dalam pembelajaran di sekolah pada tahun ajaran 2018-2019. Sampel dengan persentase kehadiran $80 \%-90 \%$ sebanyak 5 anak, dan sampel dengan persentase kehadiran 91\%-100\% sebanyak 37 anak. Hasil penelitian ini menunjukkan bahwa dari 42 anak yang berusia 5-6 tahun didapatkan hasil DDST dengan tiga kategori yaitu normal, suspek dan abnormal. Sampel paling banyak termasuk dalam kategori normal yaitu 19 anak.Pada urutan kedua yaitu kategori suspek yang terdapat 14 anak, dan urutan yang terakhir yaitu kategori abnormal yang terdapat 9 anak. Hasil penelitian ini menunjukkan adanya pengaruh program TK-A terhadap perkembangan motorik anak dilihat dari jumlah anak yang termasuk dalam kategori normal terdapat $45,2 \%$ dari jumlah sampel. Solihin dkk (2013) menyatakan bahwa mengikuti PAUD mempengaruhi secara positif terhadap perkembangan anak baik motorik kasar dan motorik halus ${ }^{13}$. 


\section{Hubungan Pemberian Program Taman Kanak-kanak Kelompok A terhadap Perkembangan Motorik}

Hasil penelitian menunjukkan bahwa pada 16 anak yang mengikuti TK-A didapatkan 9 anak kategori normal, 4 anak kategori suspek, dan 3 anak kategori abnormal. Pada 26 anak yang tidak mengikuti TK-A didapatkan 10 anak kategori normal, 10 anak kategori suspek, dan 6 anak kategori abnormal. TK-A memberikan pengaruh positif terhadap perkembangan motorik anak yaitu 9 anak $(56,3 \%)$ dari 16 anak, namun setelah dilakukan uji statistik Chi-square menunjukkan bahwa terdapat hubungan tidak signifikan antara pemberian program TK-A dengan perkembangan motorik anak pada usia 5-6 tahun dengan nilai $p=0,517$. Penelitian ini bertentangan dengan penelitian sebelumnya yang dilakukan oleh Apriliana 2015 dan Rizal 2014 bahwa program sekolah memiliki hubungan dengan perkembangan motorik kasar dan motorik halus pada anak prasekolah. Faktor yang menyebabkan penelitian ini tidak signifikan adalah beberapa faktor yang tidak di kontrol oleh peneliti diantaranya pengetahuan ibu, pola pengasuhan, pekerjaan ibu, penghasilan ayah serta kepadatan hunian rumah.

Perkembangan motorik anak dipengaruhi oleh pengetahuan ibu, dan pengetahuan dipengaruhi oleh tingkat pendidikan ibu' ${ }^{14}$. Ibu memiliki tugas pengasuhan yang tentunya berdasarkan pengetahuan yang dimilikinya. Apabila ibu memiliki pengetahuan yang tinggi, maka ibu akan lebih aktif dalam mencari informasi yang berkaitan dengan keterampilan dalam pengasuhan anak. Pernyataan yang berbeda diungkapkan oleh Moonik dkk (2015) dalam penelitiannya, yang membuktikan bahwa tidak ada hubungan antara tingkat pendidikan ibu dengan perkembangan motorik anak di Taman Kanak-kanak².

Setiap anak mendapatkan pola pengasuhan yang berbeda. Terdapat tiga jenis pola pengasuhan yang berbeda, yaitu: (1) pola pengasuhan permisif dimana orang tua cuek kepada anak dan sangat membebaskan anak dalam melakukan segala hal baik negatif maupun positif; (2) pola pengasuhan otoriter dimana orang tua mendidik dengan keras dan tidak segan untuk menghukum anak apabila melakukan hal yang tidak dikehendaki; (3) pola pengasuhan demokratif dimana orang tua realistis terhadap perkembangan anak serta akan memberikan kebebasan kepada anak untuk bereksplorasi dibawah pengawasan orang tua ${ }^{10}$. Ketiga pola pengasuhan ini berpengaruh terhadap perkembangan motorik anak, dimana anak yang mendapatkan pola pengasuhan demokratif memiliki perkembangan motorik yang lebih baik dibandingkan dengan anak yang mendapatkan pola pengasuhan permisif dan otoriter.Anak yang berada dalam pengasuhan demokratif memiliki waktu lebih banyak untuk bereksplorasi serta melakukan aktivitas untuk memenuhi kebutuhan secara mandiri. Pada pola pengasuhan demokratif perkembangan motorik anak tidak terhambat tetapi orang tua tetap memegang kendali terhadap anak ${ }^{15}$.

Pekerjaan ibu berpengaruh terhadap perkembangan motorik anak, karenaibu yang bekerja keras diluar rumah memiliki waktu interaksi yang kurang dengan anak dibandingkan dengan ibu yang bekerja dirumah. Adanya interaksi antara ibu dan anak mempermudah ibu dalam memberikan stimulasi pembelajaran motorik.Pemberian stimulasi ini meliputi rangsangan visual, permainan, komunikasi verbal, interaksi sosial, dan pengenalan waktu ibu berada dirumah ${ }^{16}$. Ibu yang bekerja beresiko 3,43 kali memiliki anak yang suspek terlambat dibandingkan ibu yang tidak bekerja ${ }^{17}$.

Faktor lain yang mempengaruhi perkembangan motorik anak yaitu sosial ekonomi. Ayah yang memiliki penghasilan tetap mempengaruhi perkembangan motorik anak akan lebih baik. Sebaliknya, ayah yang memiliki penghasilan tidak tetap mempengaruhi perkembangan anak yang kurang baik. Penghasilan ayah yang tidak tetap akan membuat ekonomi keluarga tidak stabil yang mana ekonomi keluarga penting untuk memenuhi kebutuhan dasar anak diantaranya yaitu rumah yang layak ${ }^{17}$. Rumah yang padat hunian memiliki pengaruh secara statistik terhadap perkembangan motorik anak ${ }^{2}$. Kepadatan hunian rumah dikatakan padat apabila terdapat lebih dari 2 orang dewasa dalam luas $8 \mathrm{~m}^{2}$, dan dikatakan tidak dapat apabila terdapat 2 orang dewasa dalam luas $8 \mathrm{~m}^{2} 18$. Rumah yang penuh dan sesak membuat kesehatan penghuni kurang terjamin. Anak kurang bisa beraktifitas dengan leluasa, sedangkan perkembangan motorik anak memerlukan aktifitas fisik yang membuat mereka aktif. Perkembangan motorik kasar akan berkembang dalam permainan yang aktif dan bebas, seperti bermain bola, berlarian dan lain lain ${ }^{19}$.

Pengaruh lainnya dari ekonomi keluarga tidak stabil diantaranya yaitu orang tua terbatas untuk membelikan anak alat permainan yang dapat menstimulasi motorik anak. Anak yang tidak memiliki alat mainan untuk stimulasi motorik dirumah beresiko 4,39 kali mengalami kemampuan motorik yang dicurigai terlambat ${ }^{17}$.

\section{SIMPULAN}

Simpulan yang dapat ditarik berdasarkan hasil dan diskusi yang telah dibahas yaitu:

1. Pada anak yang mengikuti Taman Kanak-kanak kelompok A memiliki presentase perkembangan motorik kategori normal lebih besar yakni $56 \%$ dari keseluruhan anak yang mengikuti, dibandingkan dengan anak yang tidak mengikuti program Taman Kanak-kanak kelompok A yang memiliki presentase perkembangan motorik kategori normal sebesar $38,5 \%$ dari keseluruhan anak yang tidak mengikuti.

2. Tidak terdapat hubungan antara pemberian program Taman Kanak-kanak kelompok A terhadap perkembangan motorik anak usia 5-6 tahun di Yayasan Mutiara Bunda Denpasar.

\section{DAFTAR PUSTAKA}

1. Mulyani, Sumantri. 2014. Perkembangan peserta didik. Jakarta: Pusat Penerbitan Universitas Terbuka.

2. Moonik, P., Lestari, H., \& Wilar, R. 2015. Faktor-Faktor yang Mempengaruhi Keterlambatan Perkembangan Anak Taman Kanak-Kanak. e-CliniC, 3(1).

3. Suryanto, S., Purwandari, H., \& Mulyono, W. A. 2014. Dukungan Keluarga Dan Sosial Dalam Pertumbuhan Dan Perkembangan Personal Sosial, Bahasa Dan Motorik Pada Balita Di Kabupaten Banyumas. Jurnal Kesehatan Masyarakat, 10(1), 103-109.Aisyah, S., Amini, M., Chandrawati, T., \& Novita, D. (2014). Perkembangan dan konsep dasar pengembangan anak usia dini.

4. Sukamti, E. R. 2001. Perkembangan Motorik Kasar Anak Usia Dini Sebagai Dasar Menuju Prestasi Olah Raga 
5. Kebudayaan, K. P. 2014. Peraturan Menteri Pendidikan dan Kebudayaan Republik Indonesia nomor 146 tahun 2014 tentang Kurikulum 2013 Pendidikan Anak Usia Dini. Jakarta: Kementerian Pendidikan dan Kebudayaan.Hikmah, Nurul. 2018. Stimulasi, Deteksi, dan Intervensi Tumbuh Kembang Anak. Cetakan Pertama. Bangkalan: STKIP PGRI Bangkalan.

6. Muryani, S., \& Elshap, D. S. 2018. Upaya Tutor Paud dalam Mempersiapkan Anak Menjelang Pendidikan Sekolah Dasar. Comm-Edu (Community Education Journal), 1(1), 9-19.

7. Indonesia, U. N. I. C. E. F. 2012. Ringkasan dan Kajian Pendidikan dan Perkembangan Anak Usia Dini.

8. Halimah, N., \& Kawuryan, F. 2010. Kesiapan memasuki sekolah dasar pada anak yang mengikuti pendidikan TK dengan yang tidak mengikuti pendidikan TK di kabupaten kudus. Jurnal Psikologi UMK: PITUTUR, 1(1), 1-8.

9. Santrock, JW. 2007. Perkembangan Anak. Jakarta: Erlangga.

10. Soetjiningsih. 2013 Konsep Dasar Tumbuh Kembang Anak. In: Ranuh IGNG, penyunting. Tumbuh Kembang Anak. Edisi 2. Jakarta: EGC.

11. Rahyubi, H. 2012. Teori-Teori dan Aplikasi Pembelajaran Motorik: Deskripsi dan Tinjauan Kritis.

12. Hikmah, Nurul. 2018. Stimulasi, Deteksi, dan Intervensi Tumbuh Kembang Anak. Cetakan Pertama. Bangkalan: STKIP PGRI Bangkalan.

13. Solihin, R. D. M., Anwar, F., \& Sukandar, D. 2013. Kaitan antara status gizi, perkembangan kognitif, dan perkembangan motorik pada anak usia prasekolah (relationship between nutritional status, cognitive development, and motor development in preschool children). Nutrition and Food Research, 36(1), 62-72.

14. Kusuma, R. 2012. Hubungan Antara Tingkat Pengetahuan lbu Tentang Tumbuh Kembang Anak Dan Perkembangan Motorik Halus Balita Di Wilayah Kerja Puskesmas Penumping Surakarta(Doctoral dissertation, Universitas Muhammadiyah Surakarta).

15. Sari, R. O. 2015. Hubungan Pola Asuh Orang Tua Dengan Perkembangan Motorik Halus Anak Usia 4-6 Tahun Di Tk Dharma Wanita Suruhan Lor Kecamatan Bandung Kabupaten Tulungagung. Jurnal IImu Keperawatan dan Kebidanan, 2(3).

16. Hikmandayani, H., \& Kartini, F. 2014. Perbedaan Perkembangan Motorik Halus Anak Usia 4-6 Tahun pada Ibu yang Bekerja dan Tidak Bekerja di Wilayah RW 39 Sleman Permai II Pangukan Tridadi Sleman (Doctoral dissertation, STIKES'Aisyiyah Yogyakarta).

17. Suryaputri, I. Y., Rosha, B. C., \& Anggraeni, D. 2014. Determinan Kemampuan Motorik Anak Berusia 2-5 Tahun: Studi Kasus di Kelurahan Kebon Kalapa Bogor. Nutrition and Food Research, 37(1), 43-50.

18. Kepmenkes, R.I. 1999. No 829/Menkes. SK/VII/1999 tentang Persyaratan Kesehatan Perumahan, Jakarta: Departemen Kesehatan RI.

19. Aisyah, S., Amini, M., Chandrawati, T., \& Novita, D. 2014. Perkembangan dan konsep dasar pengembangan anak usia dini. 